\title{
Predisposition of papillary thyroid carcinoma in a family dignosed as hereditary breast and ovarian cancer syndrome
}

\section{Herediter meme over kanser sendrom tanısı almış ailede tiroid papiller kanser birlikteliği}

\section{Zehra Dilşad Çoban*, Şefik Güran, Deniz Torun, Salih Kozan, Murat Dede, Uğur Keskin, Müfit Cemal Yenen}

Department of Medical Biology (Z. D. Çoban, MD, Prof. Ş. Güran, MD), Department of Medical Genetics (D. Torun, MD, S. Kozan, MD), Department of Obstetrics and Gynecology (Assoc. Prof. M. Dede, MD, Assist. Prof. U. Keskin, MD, Assoc. Prof. Dr. M. C. Yenen), Gülhane Military Medical Academy, TR-06010

\begin{abstract}
Hereditary breast and ovarian cancer syndrome is characterized by the familial type of breast and/or ovarian cancers diagnosed at early onset. In these families, predisposition to prostate and pancreas cancers can be seen. Here a family who had hereditary breast and ovarian cancer syndrome was presented and we also discussed the possible mechanisms in the predisposition of papillar type thyroid cancer which is common in this family. No BRCA 1 and BRCA 2 mutation had been observed in certain loci in this family. Due to the literature findings, our family is the sole example which has clinically hereditary breast and ovarian cancer syndrome diagnosis with thyroid papillary carcinoma predisposition. Here, there may be a common mechanism affected in these different tumors. So, further studies are necessary to find out affected pathways in patients having hereditary type breast and ovarian cancer who has also predispositionto papillary thyroid carcinoma.
\end{abstract}

Keywords: Hereditary breast and ovarian cancer syndrome, papillary thyroid carcinoma, BRCA 1, BRCA 2, hereditary cancers

\section{Özet}

Herediter meme over kanser sendromu, erken dönemde tanı alan ailesel tip meme ve/veya over kanseri ile karakterizedir. Ailelerde prostat ve pankreas kanserine yatkınlık görülebilir. Yazımızda herediter meme- over kanser sendromu tanısı almış bir aile sunulmakta vebu ailede sık gözlenen papiller tip tiroid kanserini oluşturabilecek nedenler tartışılmaktadır. Ailede BRCA 1 ve BRCA 2 genlerinin belli bölgelerinde mutasyon gösterilmemiştir. Ancak klinik olarak meme over kanser sendromu tanısı alan aile literatüre göre papiller tiroid kanserine yatkınlıkla tanımlanan tek örnektir. Burada tanımlanan farklı tümör tiplerinde etkilenen ortak bir mekanizma olduğu düşünülebilir. Sonuç olarak, papiller tiroid kansere yatkınlığı olan herediter meme- over kanser sendromu tanısı almış nadir ailelerde etkilenen yolakları bulmak için daha fazla araştırmaya gerek vardir.

Anahtar sözcükler: Herediter meme ve over kanseri sendromu, papiller tiroid kanseri, BRCA 1, BRCA 2, herediter kanserler

Geliş tarihi/Received: December 14, 2010; Kabul tarihi/Accepted: November 30, 2011

\section{*Corresponding author:}

Dr. Zehra Dilşad Çoban, Tıbbi Biyoloji Anabilim Dalı, Gülhane Askeri Tıp Akademisi, TR-06010 Ankara. E-posta: dilsadyilmaz_dr@hotmail.com 


\section{Introduction}

Hereditary Breast and Ovarian Cancer Syndrome (HBOCS) is an inherited tendency to develop breast, ovarian and other cancers. Inherited conditions are passed to an individual through their relatives. Although most cancers are not inherited, about $5 \%$ of people who had breast cancer and about $10 \%$ of women who had ovarian cancer have HBOCS. Having breast and/or over cancer in early age (before 40 year-old) is an important criteria for the diagnoses of HBOCS. It was shown that pancreas and prostate cancer risk is high in these families [1]. The role of hereditary mutations in BRCA1 and BRCA2 genes were well defined in the etiology of HBOCS. In ataxia telangiectasia, Fanconi anemia, Bloom syndrome, Lynch syndrome and xeroderma pigmentosum which are characterized by genomic instability, defective DNA repair mechanisms are accused. Defective DNA repair may also be an etiologic factor in some HBOCS cases. The hereditary mutations observed in HBOCS families may be the result of genomic instability [2]. Other types of cancers observed in these families are probably share similar causative mechanisms with breast and/or ovarian cancers in their etiology. So, finding the relationship among breast and/or ovarian cancers and other types of cancer is important [3]. Here, the co-existence of papillary type of thyroid cancers in a family which represented HBOCS findings was presented. The relationship between these cancers was discussed.

\section{Family history}

A proband (III-9) came to our notice with breast cancer history in her mother (II-12) and papillary type of thyroid cancer history in her elder sister (III-7). As in the family tree, proband's three aunts (II-3, II-5, II-16), her mother (II-12) and her cousin (IV-1) had breast cancer history (Table 1). Two aunts (II-3, II-5) with breast cancer also had over cancer. These cases had diagnoses before 40 year-old and died at the age of 35 because of the cancer progression. Mother of proband (II-12) and aunt of proband (II-16) had protective total abdominal hysterectomy and bilateral salphingoopheroctomy surgery. One of proband's cousins (IV-1) had breast cancer diagnosis at the age of 22. In proband's family tree, it was noticed that grandfather (I-2) died because of thyroid cancer. Proband's uncle (II-14) and proband's elder sister (III-12) had papillary type thyroid cancer.

Table 1. The pedigree of HBOCS family.

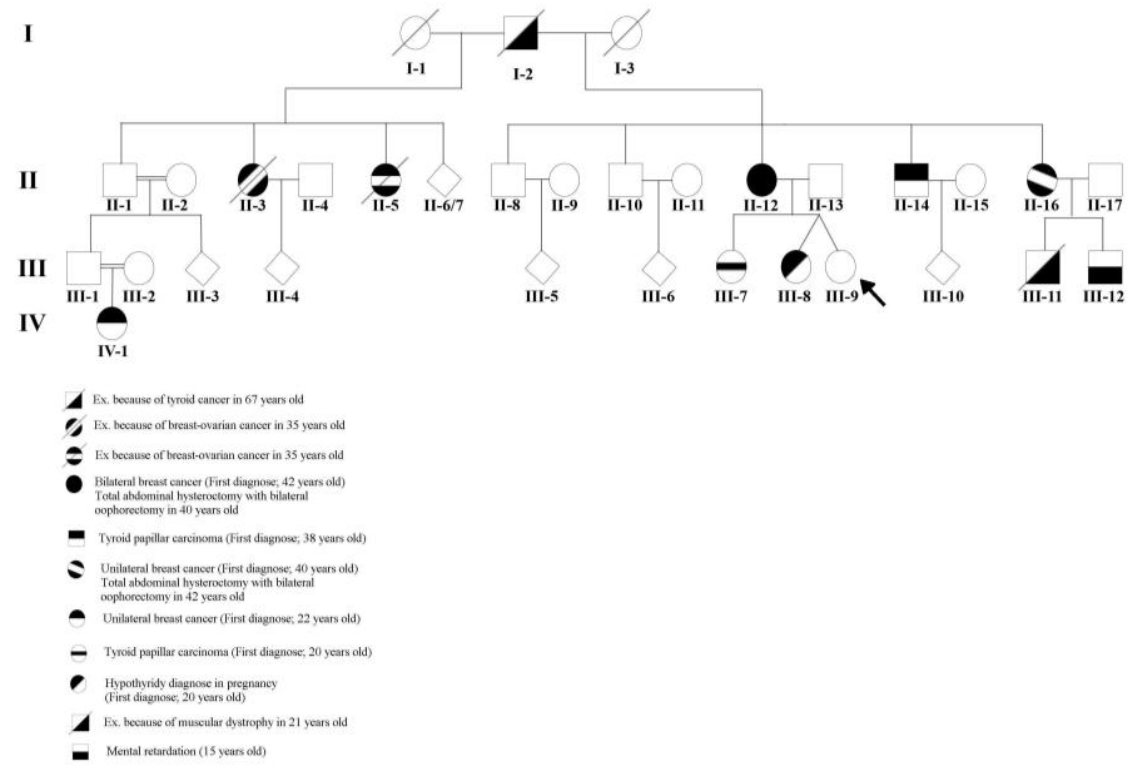

Having breast and ovarian cancers together with increased number of breast and other cancers were important for HBOCS diagnosis. Finding the cancers before 40 year-old in most cases in this family enhanced the diagnosis of HBOCS clinically. Hereditary mutations of suspected genes in such families should be analyzed for differential 
diagnosis. For this reason, the mutations of BRCA1 and BRCA2 genes were studied in our family $[4,5]$.

\section{Material and method}

Informative approval forms were assigned from proband, her mother (II-12) and her elder sister for studying hereditary mutations of BRCA1 and BRCA2 genes. DNA samples were extracted from peripheral blood by using 'Nucleospin Blood Kit' (Macherey-Nagel, Germany). In BRCA1 gene; 2312del15, 2800delAA, 3166ins5, 3600del11, 185delAG, 1294del40, 3452del4, 3875del4 and 4184del14 mutations and in BRCA2 gene; 3034/6del4, 5447del7, 5946/5delCT and 6503delTT mutations were studied with the same methodology defined by Guran et al. [4, 5]. In polymerase chain reaction (PCR) for BRCA1 gene, the reactions were done 30 cycles with $94^{\circ}-30^{\prime \prime}, 50^{\circ}-30^{\prime \prime}, 72^{\circ}-45^{\prime \prime}$ conditions. For BRCA2 gene, PCR was completed in 30 cycles with $94^{\circ}-30^{\prime \prime}, 48^{\circ}-30^{\prime \prime}$, $72^{\circ}-45^{\prime \prime}$ conditions. The PCR products were run at $10 \%$ polyacrylamide gel $(310 \mathrm{~V}, 4$ hours) for finding the specific mutations. The gels were stained with ethidium bromide. In the family, hereditary mutations of BRCA1 and BRCA2 genes were analyzed in cases II12, II-16 who had breast cancer diagnosis and III-7 who had papillary thyroid cancer diagnosis [5].

\section{Discussion}

Having two cases with breast and ovarian cancer together and three cases with breast cancers and three cases with thyroid cancers is clinically enough for HBOCS diagnosis. Having the initial diagnosis before the age of 40 in most cases also enhanced the HBOCS diagnosis clinically. In differential diagnosis, Li-Fraumeni syndrome is important. Having breast and ovarian cancer together in two cases is an important criterion for HBOCS diagnosis. As known, Li-Fraumeni syndrome has hereditary p53 mutation in $70 \%$ of families [6]. Unfortunately we did not analyze p53 mutation in this family (Table 1). In literature, the roles of hereditary BRCA1 and/or BRCA2 gene mutations were well defined in HBOCS [7]. As known, hereditary mutations which caused cancer should be found in all affected family members. We first selected the informative cases and then analyzed the mutations of BRCA1 and BRCA2 genes in peripheral blood DNA's of these cases for finding the hereditary mutation of this family [1]. BRCA1 and BRCA2 genes encode nuclear phosphoproteins that play roles in maintaining genomic instability and they also act as tumor suppressors. Different mutations had been reported in various regions of these genes in HBOCS [8, 9]. The regions screened in our panel were reported as frequently mutated regions in these two genes. In our family, no BRCA1 and BRCA2 gene mutation was observed. There may be a mutation in a different site in these genes which cause HBOCS in our family. As a second alternative, HBOCS may appear without any mutations in these genes [8-10]. HBOCS is defined as appeared by a group of gene interaction, under the same diagnoses with a non-Mendelian inheritance pattern. Because of this, there may be many different clinical findings in different cases in the same family with similar hereditary genetic alterations [10]. In our family, different clinical features under the same diagnosis in different cases was observed with the variations in disease severity (Table 1). In such syndromes, different types of cancers share similar mechanisms. So, it is important to find out the relationship in between different cancer types for understanding the mechanisms in cancer progression. With these findings, it may be possible to find out the predisposition of cancer in family members in such families $[3,7,10]$. In recent publications, the frequencies of pancreas cancers and prostate cancers were reported as high in HBOCS families [11, 12]. Hemminski et al's reported that the cases with thyroid papillary cancer diagnosis also had increased breast cancer risks in their families in Sweden [3]. In last few years, it was clarified that the families with HBOCS diagnosis had also different cancer types because of DNA damage $[2,13]$. The existence of papillary thyroid cancer in hereditary cancers is well known [3, 14]. We suppose that the co-existence of breast and/or ovarian cancer with thyroid papillary cancer is an important finding in our family which represents the evidence of common 
affected mechanisms in cancer progressions. Possibly for this reason, the cases who had thyroid papillary cancer diagnosis had initial diagnosis before 40 year-old in our family (One case had thyroid papillary cancer diagnosis in 20 and other case had thyroid papillary cancer diagnosis in 38 year-old) (Table 1) [14, 15]. So, we needed to do further molecular studies for determining the etiologic factors which possibly have roles on predisposition of cancers in such kinds of rare families [16].

\section{References}

1. Shulman LP. Hereditary breast and ovarian cancer (HBOC): clinical features and counseling for BRCA1 and BRCA2, Lynch syndrome, Cowden syndrome, and Li-Fraumeni syndrome. Obstet Gynecol Clin North Am 2010; 37: 109-33.

2. Martin SA, Hewish M, Lord CJ, Ashworth A. Genomic instability and the selection of treatments for cancer. J Pathol 2010; 220: 281-9.

3. Hemminki K, Eng C, Chen B. Familial risks for nonmedullary thyroid cancer. J Clin Endocrinol Metab 2005; 90: 5747-53.

4. Güran S, Safali M. A case of neurofibromatosis and breast cancer: loss of heterozygosity of NF1 in breast cancer. Cancer Genet Cytogenet 2005; 156: 86-8.

5. Güran S, Ozet A, Dede M, Gille JJ, Yenen MC. Hereditary breast cancer syndromes in a Turkish population. Results of molecular germline analysis. Cancer Genet Cytogenet 2005; 160: 164-8.

6. Saxena R, Kohli S, Guleria K, Verma IC. Novel human pathological mutations. Gene symbol: TP53. Disease: Li-Fraumeni syndrome. Hum Genet 2010; 127: 480.

7. Lynch HT, Casey MJ, Snyder CL, Bewtra C, Lynch JF, Butts M, Godwin AK. Hereditary ovarian carcinoma: heterogeneity, molecular genetics, pathology, and management. Mol Oncol 2009; 3: 97-137.

8. Goldberg JI, Borgen PI. Breast cancer susceptibility testing: past, present and future. Expert Rev Anticancer Ther 2006; 6: 1205-14.

9. Bahçe M. Genetics in ovarian tumors. Turkiye Klinikleri J Surg Med Sci 2007; 3: 5-9.

10. Hitchins MP, Ward RL. Constitutional (germline) MLH1 epimutation as an aetiological mechanism for hereditary non-polyposis colorectal cancer. J Med Genet 2009; 46: 793-802.

11. Landi S. Genetic predisposition and environmental risk factors to pancreatic cancer: A review of the literature. Mutat Res 2009; 681: 299-307.

12. Futreal PA, Coin L, Marshall M, Down T, Hubbard T, Wooster R, Rahman N, Stratton MR. A census of human cancer genes. Nat Rev Cancer 2004; 4: 177-83.

13. Jensen UB, Sunde L, Timshel S, Halvarsson B, Nissen A, Bernstein I, Nilbert M. Mismatch repair defective breast cancer in the hereditary nonpolyposis colorectal cancer syndrome. Breast Cancer Res Treat 2010; 120: 777-82.

14. Yağc1 G, Dede M, Guran S, Yenen MC, Durukan AH, Safali M. A papillary thyroid carcinoma case associated with hereditary colon carcinoma due to familial adenomatous polyposis with no hereditary mutation finding. Int $\mathbf{J}$ Colorectal Dis 2007; 22: 725-6.

15. Nagy R, Sweet K, Eng C. Highly penetrant hereditary cancer syndromes. Oncogene 2004; 23: 6445-70.

16. Oğur G: Genes, chromosomes and cancer. Turkiye Klinikleri J Pediatr Sci 2005; 1: 73-92. 